Article

\title{
Environmental Effects of Sewage Sludge Carbonization and Other Treatment Alternatives
}

\author{
Ning-Yi Wang, Chun-Hao Shih, Pei-Te Chiueh * and Yu-Fong Huang \\ Graduate Institute of Environmental Engineering, National Taiwan University, No.71 Chou-Shan Road, \\ Taipei 106, Taiwan; E-Mails: r99541130@ntu.edu.tw (N.-Y.W.); r00541122@ntu.edu.tw (C.-H.S.); \\ d94541001@ntu.edu.tw (Y.-F.H.)
}

* Author to whom correspondence should be addressed; E-Mail: ptchueh@ntu.edu.tw; Tel.: +886-2-3366-2798; Fax: +886-2-2392-8830.

Received: 10 December 2012; in revised form: 21 January 2013 / Accepted: 31 January 2013 / Published: 7 February 2013

\begin{abstract}
Carbonization is a newly developed process that converts sewage sludge to biocoal, a type of solid biomass that can partially substitute for coal during power generation. This study presents an assessment of the environmental effects of various sewage sludge treatment processes, including carbonization, direct landfills, co-incineration with municipal solid waste, and mono-incineration in Taiwan. This assessment was conducted using the life cycle assessment software SimaPro 7.2 and the IMPACT2002+ model. Results show that carbonization is the best approach for sewage sludge treatment, followed in descending order by co-incineration with municipal solid waste, direct landfills, and mono-incineration. The carbonization process has noticeable positive effects in the environmental impact categories of terrestrial ecotoxicity, aquatic ecotoxicity, land occupation, ionizing radiation, aquatic eutrophication, non-renewable energy, and mineral extraction. For the emission quantity of greenhouse gases, landfilling has the greatest impact (296.9 $\mathrm{kg} \mathrm{CO}$ eq./t sludge), followed by mono-incineration $(232.2 \mathrm{~kg} \mathrm{CO}$ eq./t sludge) and carbonization (146.1 $\mathrm{kg} \mathrm{CO}$ eq./t sludge). Co-incineration with municipal solid waste has the benefit of reducing green house gas emission $(-15.4 \mathrm{~kg} \mathrm{CO}$ eq./t sludge). In the aspect of energy recovery, sewerage sludge that has been pretreated by thickening, digestion, and dewatering still retains a high moisture content, and thus requires a significant amount of energy use when used as a substitute solid fuel. Therefore, the carbonization of sewage sludge would be a more sustainable option if the energy delivery and integration processes are made more efficient.
\end{abstract}


Keywords: sewage sludge; carbonization; life cycle assessment; biocoal; environmental impact

\section{Introduction}

Because of high population growth and urban planning in Taiwan, the prevalence of public sewage systems reached $30 \%$ of the population in 2012 , and is expected to increase to $36 \%$ by 2014 [1]. Thus, sewage sludge production will increase with the expansion of the sewage treatment system, and should reach up to 1040 t/day by 2014 [2]. Sewage sludge generally contains pollutants such as human pathogenic organisms, and must be disposed of in ways that reduce environmental and public health effects.

Most sewage sludge in Taiwan is currently disposed of in landfills, with the remainder being co-incinerated with municipal solid waste (MSW). Existing crane and grapple-feeding devices have difficulty handling the pasty sludge cake with MSW, and the sludge degrades combustion efficiency. Thus, the co-incineration ratio is limited. Some MSW incineration plants even ban sewage sludge. The scarcity of available landfills and limited capacity of co-incineration are pressing problems. Other solutions for handling sewage sludge in more environmentally friendly ways, and recovering its energy, have caused great concern in recent years.

The imported energy ratio in Taiwan is as high as $99.4 \%$, and energy security is unfavorable [3]. Finding alternative energy sources, such as bioenergy, is necessary. Carbonization technology can transform sludge into a carbon-containing product that can be used as biocoal and co-fired with fossil coal to generate electricity in power plants [4-8]. Carbonizing sludge reduces its volume to approximately one-eighth of the sludge cake, increases its calorific value, removes its odor, and improves its combustibility and grindability, making it a better co-firing material for pulverized coal power plants $[4,5,9]$. Reference plants applying sewage sludge carbonization technology in Japan and North America have successfully demonstrated its feasibility [8-11]. These applications advance the goals of using sewage sludge as an energy resource and simultaneously reducing greenhouse gas emissions and coal extraction.

Life cycle assessment (LCA) is a method of evaluating the environmental effects associated with a product, process, or service throughout its life cycle. The LCA method is generally performed according to ISO14040 standards, which define the principles and framework of LCA [12]. Researchers have also applied LCA to sewage sludge management. Hospido et al. [13] compared three alternative sewage sludge post-treatments (agricultural use, incineration, and pyrolysis) and then assessed the energy reuse strategy used in pyrolysis. Hong et al. [14] combined LCA and LCC (i.e., life cycle cost) to estimate the environmental and economic effects of six alternative sewage sludge treatments. Their results indicate that dewatered sludge combined with electric melting is an environmentally optimal and economically affordable method. Murray et al. [15] also applied life cycle environmental and life cycle cost assessments to nine alternative sewage sludge treatments. Their results indicate that coal-fired incineration is the most environmentally and economically costly of all treatments. However, no study has presented the LCA of sewage sludge carbonization. Because 
carbonization is increasingly being adopted in several countries and is a candidate for sludge treatment in Taiwan, understanding the potential effects of this biomass usage method is necessary.

The objectives of this study are to simulate the sewage sludge carbonization process, using local sludge properties, to evaluate the environmental effects and benefits of the carbonization process using LCA. This study also uses LCA to investigate current approaches for sewage sludge treatment, including direct landfills, co-incineration with MSW, and mono-incineration for comparison.

\section{Simulation of the Sewage Sludge Carbonization Process}

Because no inventory is available within the existing LCA database applicable to carbonization, this study adopts an energy model developed by Maski et al. for biomass pretreatment [16] and previous research results of biomass torrefaction [17-19]. This study also refers to a batch-type carbonation experiment, conducted by Park and Jang [4], specific to dried sewage sludge at $300-500{ }^{\circ} \mathrm{C}$ for $30 \mathrm{~min}$. Koga et al. [8] also reported a sewage sludge carbonization system handling 40-60 kg/h of dewatered sludge at a $500{ }^{\circ} \mathrm{C}$ carbonation temperature to produce biocoal. Therefore, the simulated carbonization process in this study assumed dewatered sludge to be bone dried at $100{ }^{\circ} \mathrm{C}$, and subsequently carbonized at $450{ }^{\circ} \mathrm{C}$ for $30 \mathrm{~min}$ in the absence of oxygen. Carbonized liquid and volatile gases were collected and recovered for their heat energy [20,21], which was supplied to the drying and carbonization units through a combustor and heat exchanger. The final carbonized product or biocoal, which had properties similar to fossil coal, can generate carbon neutral bioenergy at a pulverized coal power plant.

The following equations were used to simulate the sewage sludge carbonization process:

(1) The energy use of a drying unit $\left(E_{R, D}, \mathrm{MJ} / \mathrm{kg}\right)$ is represented by:

$$
E_{R, D}=\left\{\left(\frac{M_{w e t}}{100}\right) \times\left[C_{p, w} \times\left(373-T_{i}\right)+L_{v, w}\right]+\left(\frac{D B_{w e t}}{100}\right) \times C_{p, b} \times\left(373-T_{i}\right)\right\} \times e_{f, d}^{-1}
$$

where $M_{\text {wet }}$ (wt \%) is the moisture content of sewage sludge; $D B_{\text {wet }}$ (wt \%) is the percentage of dry solid in sewage sludge (note: $\left.M_{\text {wet }}+D B_{\text {wet }}=100 \mathrm{wt} \%\right) ; C_{p, w}(\mathrm{MJ} / \mathrm{kg} \mathrm{K})$ is the specific heat of water $=0.004187 \mathrm{MJ} / \mathrm{kg} \mathrm{K} ; \mathrm{T}_{\mathrm{i}}(\mathrm{K})$ is the initial temperature of sewage sludge $=298 \mathrm{~K} ; L_{v, w}(\mathrm{MJ} / \mathrm{kg})$ is the latent heat of water at its boiling point $=2.27 \mathrm{MJ} / \mathrm{kg} ; \mathrm{C}_{\mathrm{p}, \mathrm{b}}(\mathrm{MJ} / \mathrm{kg} \mathrm{K})$ is the specific heat of sewage sludge $=0.001763 \mathrm{MJ} / \mathrm{kg} \mathrm{K}[18]$; and $e_{f, D}$ is the efficiency of the drying unit (assumed to be 0.85 in this study, a relatively high efficiency).

(2) The energy use of a carbonization unit $\left(E_{R, C}, \mathrm{MJ} / \mathrm{kg}\right)$ is represented by:

$$
E_{R, C}=\frac{C_{p, b} \times\left(T_{C}-373\right)}{e_{f, c}}
$$

where $T_{C}(\mathrm{~K})$ is the carbonization temperature, and $\mathrm{e}_{\mathrm{f}, \mathrm{C}}$ is the efficiency of the carbonization unit, set to 0.85 in this study.

(3) In a combustor and heat exchanger, available energy is derived from the combustion of volatile gas and carbonized liquid, where available energy from volatile gas $\left(E_{A, C G}, \mathrm{MJ} / \mathrm{kg}\right)$ and available energy from carbonized liquid $\left(E_{A, C L}, \mathrm{MJ} / \mathrm{kg}\right)$ are represented by:

$$
E_{A, C G}=\frac{1}{3} L H V_{\text {volatile }} \times D B \times y_{M G} \times e_{f, c} \times\left(1-H_{L}\right)
$$


and:

$$
E_{A, C L}=\frac{1}{3} L H V_{\text {liquid }} \times D B \times y_{M L} \times e_{f, c} \times\left(1-H_{L}\right)
$$

The terms $L H V_{\text {volatile }}(\mathrm{MJ} / \mathrm{kg})$ and $L H V_{\text {liquid }}(\mathrm{MJ} / \mathrm{kg})$ represent the heating value of the volatile gas and carbonized liquid generated by the carbonization unit, respectively, and $D B(\mathrm{~kg})$ is the weight of dried sludge, $y_{M G}$ is the volatile gas yield, $y_{M L}$ is the carbonized liquid yield [calculated by Equation (5)], $e_{f, C}$ is the efficiency of the combustor unit (assumed to be 0.85 ), and $H_{L}$ is the heat loss of the heat exchanger (assumed to be $0.5 \%$ ).

(4) The product yield $\left(y_{M}\right)$ is defined according to mass by [22]:

$$
y_{M}=\left(\frac{m_{\text {out }}}{m_{\text {in }}}\right)_{d a f}
$$

where $m_{i n}$ is the mass of the biomass input, and $m_{\text {out }}$ is the mass of product output of a carbonization unit (note: $d a f=$ dry and ash free).

Figure 1 shows the simulation results of sewage sludge carbonization based on the properties of dewatered sewage sludge after anaerobic digestion from a local sewage treatment plant and experimental results of carbonization yield [23,24] (Table 1). Mass and energy balance calculations show a 0.08 (daf) product yield $\left(y_{M}\right), 3.19 \mathrm{MJ} / \mathrm{kg}$ total energy required of units, $0.14 \mathrm{MJ} / \mathrm{kg}$ available energy from volatile gas $\left(E_{A, C G}\right)$, and $0.5 \mathrm{MJ} / \mathrm{kg}$ available energy from carbonized liquid $\left(E_{A, C L}\right)$. The supplementary information (Table A1) explains the nomenclature and provides parameter values. Although the simulation process is a simplified form, this approach presents a feasible method to access the LCA of sewage sludge carbonization. By changing the efficiencies of the drying unit and carbonization unit from 0.85 to 0.65 (decreasing 20\%), the overall required energy increases $25 \%$ and the available energy from volatile gas and carbonized liquid decreases $19 \%$. The influence of the assumed efficiency of each unit on the LCA results can be estimated accordingly.

Figure 1. Mass and energy balances of the sewage sludge carbonization process.

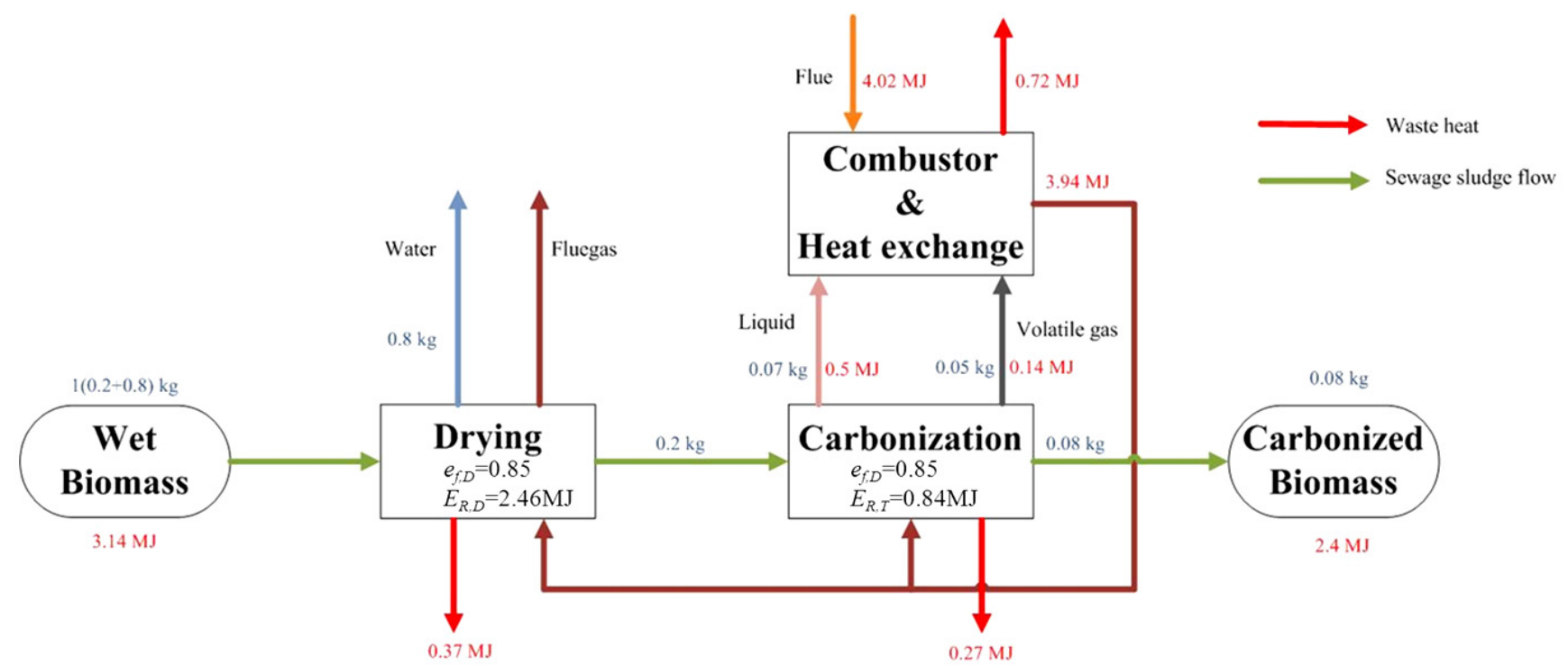


Table 1. Sewage sludge characteristics.

\begin{tabular}{lc}
\hline Dewatered sludge characteristics* & Value \\
\hline Moisture (wt \%) & 80 \\
High heating value ${ }_{\text {dry }}(\mathrm{MJ} / \mathrm{kg})$ & 15.18 \\
\hline Proximate analysis (dry basis, wt \%) & \\
\hline Ash content & 35.2 \\
Volatile matter & 64.8 \\
\hline Elemental analysis (dry and ash free basis, wt \%) & 54.60 \\
\hline $\mathrm{C}$ & 7.69 \\
$\mathrm{H}$ & 4.52 \\
$\mathrm{~N}$ & 30.29 \\
$\mathrm{O}$ & 2.52 \\
$\mathrm{~S}$ & \\
\hline Experimental results of carbonization yield (dry and ash free basis, wt $\%)^{* * *}$ & 39.14 \\
\hline Solid yield & 34.09 \\
Liquid yield & 26.77 \\
Volatile gas & \\
\hline
\end{tabular}

Notes: * Source: [2]; ** Source: $[23,24]$, recalculated by this study at $450{ }^{\circ} \mathrm{C}$.

\section{Materials and Methods of LCA}

The LCA software SimaPro 7.2 (PRé Consultants, Amersfoort, The Netherlands) was used to assess the environmental effects of four sewage sludge treatment scenarios: carbonization, mono-incineration, landfill, and co-incineration with MSW. The IMPACT2002+ model (included in SimaPro 7.2) was used to characterize environmental effects [25] by combining midpoint assessments with various damage categories.

\subsection{Functional Unit}

The functional unit is defined as the unit for comparison in a life cycle inventory. Specifically, this study adopts the management of $1 \mathrm{t}$ of dewatered sludge (moisture content $80 \%$ ) as the functional unit on which all material and energy use, energy recovery, and emissions are based.

\subsection{System Boundaries}

Dewatered sludge after anaerobic digestion from the Dihua sewage treatment plant in Taipei City (Taiwan) was adopted as an example for evaluation in this study, and its characteristics are detailed in reference [26]. Figure 2 shows the system boundaries of the study: carbonization and mono-incineration were hypothesized alternatives, whereas landfill and co-incineration with MSW were modeled according to current practice. The considerations for each system included the following factors:

(a) Carbonization of dewatered sludge and co-firing of biocoal (1\% by heat input) at the Linkou coal power plant, New Taipei City, Taiwan, considering coal substitution, electricity generation, and heat recovery. 
(b) Mono-incineration of dewatered sludge at certain industrial waste incineration plants without production of electrical energy, considering heat recovery.

(c) Sanitary landfill of dewatered sludge at Wujie Township, Yilan County, Taiwan, without considering methane recovery.

(d) Co-incineration of dewatered sludge ( $3 \%$ by weight) with MSW at the Beitou MSW incineration plant, New Taipei City, Taiwan, in which waste to electricity was considered.

Figure 2. System boundary. Values in parentheses are transportation distances.

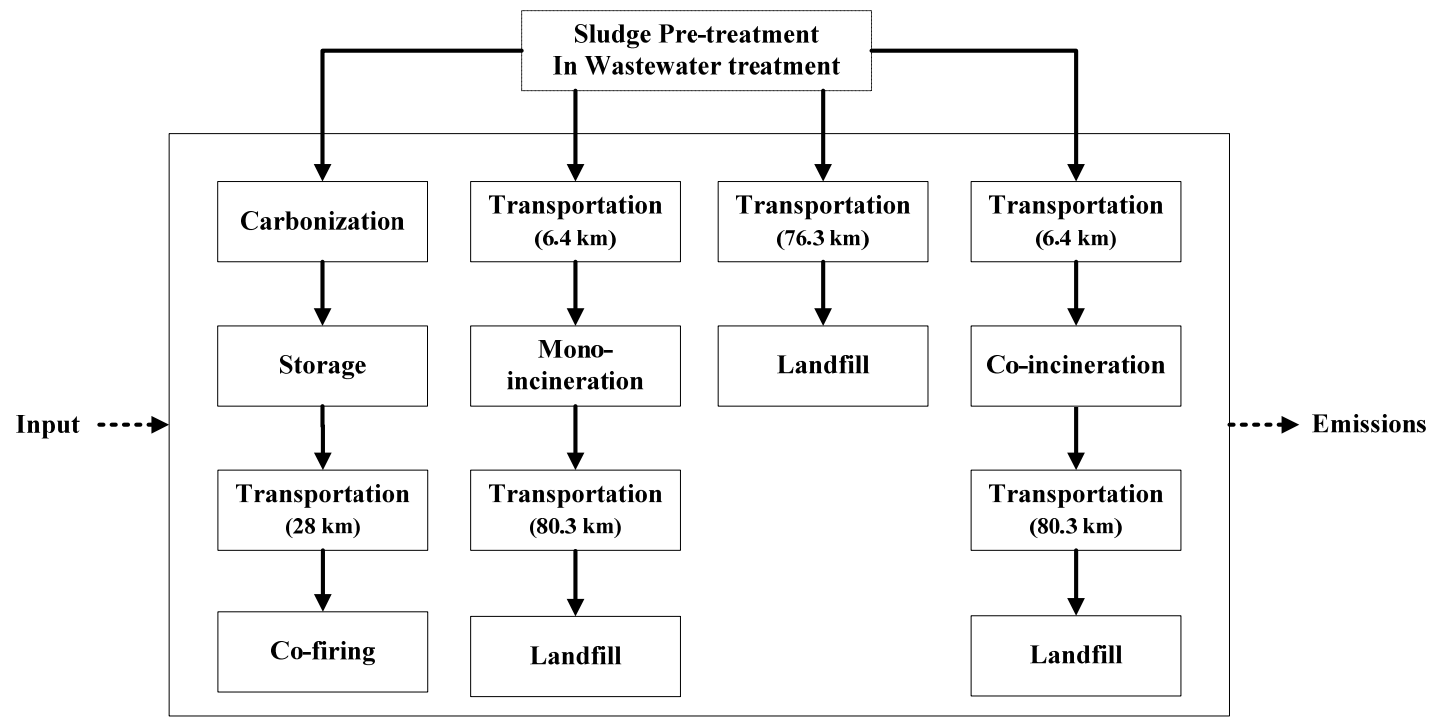

\subsection{Inventory Data Source}

\subsubsection{Energy Use and Recovery}

This study investigates the inventories of energy use and recovery to assess the potential net energy benefits of different sludge treatments. For all scenarios, electricity was the primary energy consumed, and its impacts on environment were characterized by the actual electricity structure in Taiwan (coal-fired: 50\%; LNG-fired: $25 \%$; nuclear: 17\%; oil-fired: $4 \%$; hydro: $3 \%$; waste: $1 \%$ ). For the assessment of energy recovery in the carbonization scenario, the quantity of recycled heat (640 MJ), coal substitution $(80 \mathrm{~kg})$, and electricity generation $(105 \mathrm{kWh})$ resulting from co-firing was derived from simulation results and heating values conversion of biocoal (Figure 1). The inventory also includes the effects of sludge transportation by trucks ( $>28 \mathrm{t}$ ) and coal substitution on coal mining and ocean shipping.

Table A2 lists energy and material inputs for mono-incineration scenario. The mono-incineration scenario recovered heat energy (349.4 MJ) during the incineration process [13]. The co-incineration scenario generated electricity $(0.21 \mathrm{kWh})$ by the co-incineration of sludge with MSW [27]. The landfill scenario recovered no energy (methane).

\subsubsection{Data Quality}

Other inventory data used in this study were obtained from three main sources:

(1) SimaPro 7.2 databases: The LCA, Ecoinvent, Industry data 2.0, IDEMAT 2001, and LCAfood databases contained in SimaPro software were used for the inventory of the four scenarios 
(carbonization, direct landfills, co-incineration with municipal solid waste, and mono-incineration). This study also investigates the variables of input, output, emission, and waste disposal stages.

(2) Operational data: Data used for the co-incineration scenario, such as electricity generation and electricity consumption, were obtained from practical data logging at the Beitou MSW incinerator Taiwan.

(3) Literature and theoretical calculation: Neither carbonization nor mono-incineration of sewage sludge are practiced in Taiwan. Therefore, the inventory of the mono-incineration scenario was derived from previous studies, and theoretical calculations were applied to the carbonization scenario based on Equations (1)-(5).

\section{Impact Assessment and Discussion}

\subsection{Carbonization Scenario}

The sewage sludge carbonization process was divided into several steps to identify the major sources of environmental effects and their consequences (Table 2). Results indicate that the drying unit created the highest environmental effect of all categories. Non-renewable energy and global warming were the categories most affected by drying and carbonization because of their high energy use. Recycling heat during carbonization had a positive effect on all categories. In addition, biocoal storage increased particulate emissions and land use.

Table 2. Characterization of the carbonization scenario.

\begin{tabular}{|c|c|c|c|c|c|c|c|c|c|c|}
\hline \multicolumn{3}{|c|}{ Carbonization and co-firing } & \multicolumn{5}{|c|}{ Carbonization process } & \multicolumn{3}{|c|}{$\begin{array}{c}\text { Co-firing of biocoal and } \\
\text { coal in power plant } \\
\end{array}$} \\
\hline \multirow{2}{*}{$\begin{array}{l}\text { Impact } \\
\text { category }\end{array}$} & \multirow{2}{*}{ Unit } & \multirow{2}{*}{ Total } & \multirow{2}{*}{ Drying } & \multirow{2}{*}{ Carbonization } & \multicolumn{2}{|c|}{ Energy Carbonization } & \multirow{2}{*}{$\begin{array}{l}\text { Biocoal } \\
\text { Storage } \\
\end{array}$} & \multirow{2}{*}{ Co-firing } & \multirow{2}{*}{$\begin{array}{r}\text { Alternative } \\
\text { coal }\end{array}$} & \multirow{2}{*}{$\begin{array}{r}\text { Electricity } \\
\text { production }\end{array}$} \\
\hline & & & & & Reuse & Facility & & & & \\
\hline Carcinogens & $\mathrm{kg} \mathrm{C}_{2} \mathrm{H}_{3} \mathrm{Cl}$ eq. & 1.98 & 1.66 & 0.51 & -0.32 & 0 & 0 & 0.32 & -0.08 & -0.11 \\
\hline Non-carcinogens & $\mathrm{kg} \mathrm{C}_{2} \mathrm{H}_{3} \mathrm{Cl}$ eq. & 2.82 & 0.23 & 0.04 & -0.02 & 0 & 0 & 2.96 & -0.17 & -0.22 \\
\hline Respiratory inorganics & $\mathrm{kg} \mathrm{PM}_{2.5}$ eq. & 0.08 & 0.05 & 0.01 & 0.00 & 0 & 0.04 & 0.08 & -0.04 & -0.06 \\
\hline Ionizing radiation & $\mathrm{Bq} \mathrm{C}^{-14}$ eq. & -1182 & 1556.3 & 158.23 & -39.90 & 0.21 & 0 & 22.68 & -274.61 & $-2,605.29$ \\
\hline Ozone layer depletion & $\mathrm{kg} \mathrm{CFC}^{-11}$ eq. & 0.00003 & 0.00 & 0.00 & 0.00 & 0 & 0 & 0.000001 & -0.000001 & -0.000002 \\
\hline Respiratory organics & $\mathrm{kg} \mathrm{C}_{2} \mathrm{H}_{4}$ eq. & 0.03 & 0.05 & 0.01 & -0.01 & 0 & 0 & 0.004 & -0.02 & -0.01 \\
\hline Aquatic ecotoxicity & kg TEG water & $-22,412$ & $3,952.9$ & 671.52 & -326.1 & 0.94 & 0 & 1,546 & $-23,768.1$ & $-4,489.73$ \\
\hline Terrestrial ecotoxicity & kg TEG soil & $-6,003$ & 933.3 & 161.68 & -79.61 & 0.31 & 0 & 60.87 & $-6,044.6$ & $-1,035.48$ \\
\hline Terrestrial acid/nutria & $\mathrm{kg} \mathrm{SO}_{2}$ eq. & 1.12 & 1.26 & 0.24 & -0.12 & 0 & 0 & 2.47 & -1.45 & -1.29 \\
\hline Land occupation & $\begin{array}{l}\mathrm{m}^{2} \text { land } \\
\text { arable } \cdot \text { year }\end{array}$ & -0.85 & 0.15 & 0.02 & -0.01 & 0 & 0.06 & 0.02 & -0.88 & -0.22 \\
\hline Aquatic acidification & $\mathrm{kg} \mathrm{SO}_{2}$ eq. & 0.36 & 0.34 & 0.06 & -0.03 & 0 & 0 & 0.65 & -0.27 & -0.39 \\
\hline Aquatic eutrophication & $\mathrm{kg} \mathrm{PO}_{4}$ eq. & -0.0004 & 0.00 & 0.00 & 0.00 & 0 & 0.0000002 & 0.0001 & -0.0006 & -0.001 \\
\hline Global warming & $\mathrm{kg} \mathrm{CO}_{2}$ eq. & 146.62 & 209.02 & 55.79 & -34.15 & 0.01 & 0 & 9.37 & -16.00 & -77.42 \\
\hline Non-renewable energy & MJ primary & -1122.9 & $3,896.4$ & $1,062.72$ & -655.6 & 0.15 & 0 & 15.33 & $-4,178.8$ & $-1,263.00$ \\
\hline Mineral extraction & MJ surplus & -0.02 & 0.18 & 0.04 & -0.02 & 0 & 0 & 0.02 & -0.13 & -0.12 \\
\hline
\end{tabular}

This study assumes that the biocoal produced from the carbonization process will be used for co-firing with coal in power plants. As Table 2 shows, the overall results of the carbonization scenario generated positive effects in the categories of terrestrial ecotoxicity, aquatic ecotoxicity, land 
occupation, ionizing radiation, aquatic eutrophication, non-renewable energy, and mineral extraction. These benefits resulted primarily from coal substitution and bioelectricity generation.

\subsection{Comparison of Scenarios}

In addition to the benefits and advantages of the carbonization scenario, this study presents a comparison of the results of four sewage sludge treatment scenarios. Figure 3 shows the characterization of the midpoint environmental effects for these scenarios. The carbonization scenario had the highest effect on ozone layer depletion and respiratory organics. Mono-incineration had the greatest effect on mineral extraction, non-renewable energy, aquatic acidification, terrestrial acid/nutrients, terrestrial ecotoxicity, ionizing radiation, and respiratory inorganics. The landfill scenario had the greatest effect on global warming, aquatic eutrophication, and land occupation. Co-incineration had the greatest effect on carcinogens and non-carcinogens and aquatic ecotoxicity.

Figure 3. Characterization of the mid-point environmental effects of four sludge-handling scenarios.

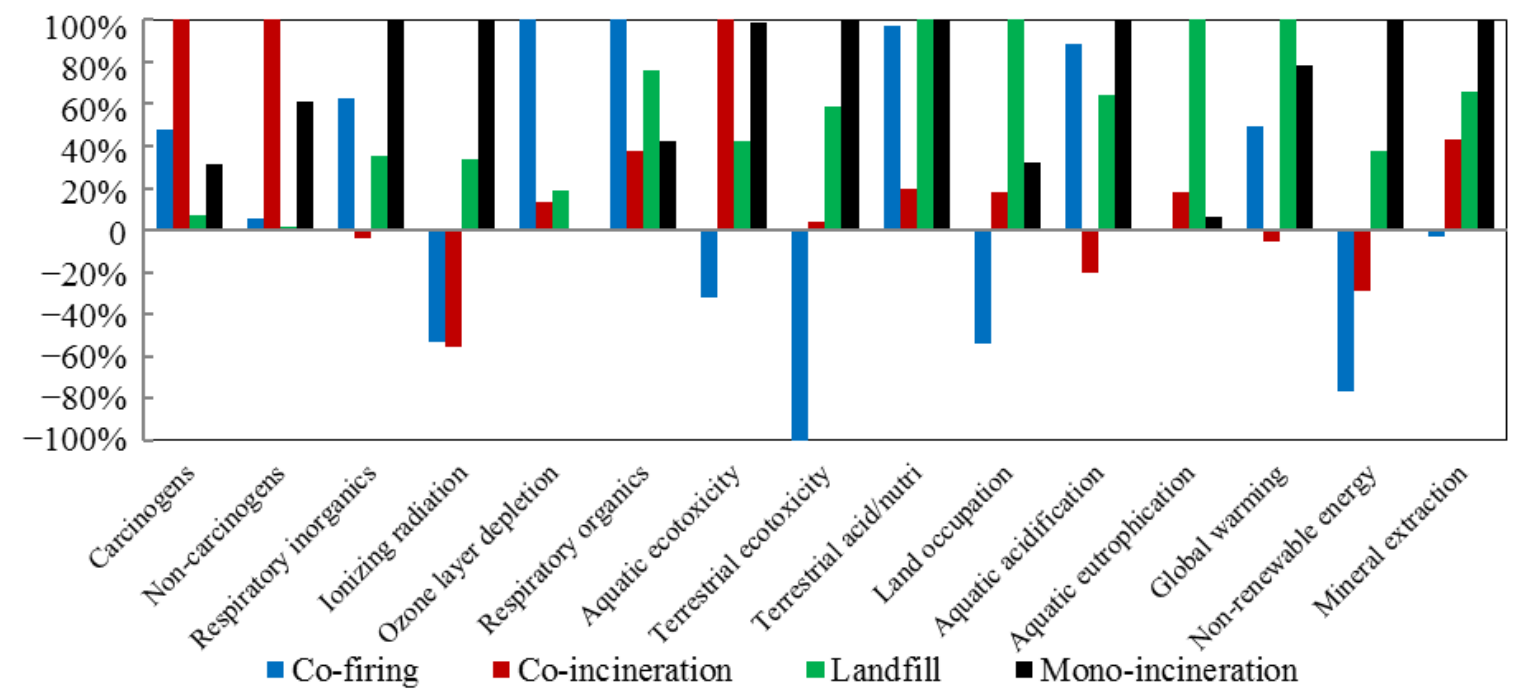

Table 3 shows the normalized results of the four scenarios for various damage categories: human health, ecosystem quality, climate change, and resources. Regarding damage to human health, mono-incineration and co-incineration damaged human health than the other scenarios. The effects of mono-incineration were caused primarily by the emission of particulates and nitrogen oxides, combined with the effluence of antimony and arsenic ions. The carbonization scenario had a beneficial effect on ecosystem quality because of the substitution of biocoal for some coal in the co-firing process. The landfill scenario had the greatest effect on climate change because of the greenhouse gas emitted during the landfill process. Mono-incineration had the greatest negative effect on resources because of its high energy use. Carbonization and co-incineration had positive effects on resources because of coal substitution and bioelectricity generation.

The single score column in Table 3 shows that the overall degree of environmental effect was mono-incineration $>$ landfill $>$ co-incineration $>$ carbonization. Thus, carbonization combined with co-firing was the best scenario because it had the lowest environmental effect, followed by co-incineration, landfill, and mono-incineration in descending order. Table 3 shows the potential effect of the scenarios 
on global warming. Ranked in descending order of their greenhouse gas emissions, the scenarios were landfill (296.9 $\mathrm{kg} \mathrm{CO}_{2}$ eq.) $>$ mono-incineration (232.2 $\mathrm{kg} \mathrm{CO}_{2}$ eq.) $>$ carbonization (146.1 $\mathrm{kg} \mathrm{CO}_{2}$ eq.) > co-incineration ( $-15.4 \mathrm{~kg} \mathrm{CO}_{2}$ eq.). Landfills had the highest value because of the methane and carbon dioxide released during sludge decomposition. The greenhouse gas emissions of mono-incineration and carbonization primarily resulted from energy use. Only co-incineration showed a reduction in greenhouse gas emissions because of the bioelectricity generated during the incineration process.

Table 3. Results of normalization, single score, and GHG emission in four sludge-handling scenarios.

\begin{tabular}{cccccccc}
\hline \multirow{2}{*}{ Item } & \multicolumn{3}{c}{ Normalized results of damage categories } & \multicolumn{2}{c}{ Single score GHG emission } \\
\cline { 2 - 7 } & Human health & Ecosystem quality & Climate change & Resources & & \\
\hline Unit & - & - & - & - & $\mathrm{Pt}$ & $\mathrm{kg} \mathrm{CO} 2 \mathrm{eq}$. \\
Carbonization & 0.0095 & -0.0035 & 0.0148 & -0.0074 & 0.013428 & 146.6 \\
Co-incineration & 0.0204 & 0.0003 & -0.0016 & -0.0028 & 0.016414 & -15.4 \\
Landfill & 0.0048 & 0.0008 & 0.0300 & 0.0036 & 0.039208 & 296.9 \\
Mono-incineration & 0.0246 & 0.0012 & 0.0236 & 0.0097 & 0.059045 & 233.2 \\
\hline
\end{tabular}

The evaluation of greenhouse gas emissions in this study is similar to that of other studies, with the exception of the novel presented carbonization scenario. Houillon and Jolliet [28] assessed a sludge treatment method consisting of landfill, incineration, and pyrolysis. Their results show that the landfill treatment returned the highest greenhouse gas emissions. Lundin et al. [29] and Svanstrom et al. [30] compared greenhouse gas emissions of sludge treatments, indicating that co-incineration was beneficial in reducing greenhouse gas emissions. However, the greenhouse gas emission calculations for the carbonization scenario were higher than that for co-incineration because of the energy used (in particular by the drying unit) during the carbonization process. According to the current study results, carbonization combined with co-firing is less advantageous than co-incineration with MSW alone because of two possible reasons. In the current study, the water content of the dried sludge was assumed to be $0 \%$, whereas Koga et al. [8] reported that dewatered sludge was only partially dried (i.e., until reaching $25 \%$ moisture content) before the carbonization step. In addition, this study assumes that the carbonization temperature is $450{ }^{\circ} \mathrm{C}$ (compared with $500{ }^{\circ} \mathrm{C}$ by Koga et al. [8]). This lower temperature may be more efficient and reduce energy use [4]. However, Lundin et al. [29] showed that the cost of co-incineration with waste was higher than using it in agricultural applications and incineration or fractionation combined with phosphorus recovery. Therefore, the co-incineration scenario may incur higher costs than other scenarios. Thus, environmental and economic effects should be cautiously considered when evaluating potential sludge treatments in the future.

\subsection{Sensitivity Analysis}

Energy use is crucial in sewage sludge treatment options. Because all four scenarios in this study consume electricity, sensitivity analysis was performed using electricity consumption variances of $\pm 10 \%$ and $\pm 20 \%$. The variations of single scores of the four sludge treatment scenarios were analyzed accordingly (Table 4). Results indicate that the co-incineration scenario was most sensitive to variation in electricity consumption. When the electricity consumption increased by $20 \%$, the overall effect 
increased by $36 \%$ (Figure 4). Variation of electricity consumption had little effect on the environmental impacts of the landfill scenario.

Table 4. Results of single scores for electricity consumption variances.

\begin{tabular}{ccccc}
\hline Variation & Co-firing & Co-incineration & Landfill & Mono-incineration \\
\hline Electricity -20\% & $1.09 \times 10^{-2}$ & $1.05 \times 10^{-2}$ & $3.91 \times 10^{-2}$ & $5.56 \times 10^{-2}$ \\
Electricity -10\% & $1.22 \times 10^{-2}$ & $1.34 \times 10^{-2}$ & $3.92 \times 10^{-2}$ & $5.73 \times 10^{-2}$ \\
Original case & $1.34 \times 10^{-2}$ & $1.64 \times 10^{-2}$ & $3.92 \times 10^{-2}$ & $5.90 \times 10^{-2}$ \\
Electricity $+10 \%$ & $1.47 \times 10^{-2}$ & $1.94 \times 10^{-2}$ & $3.93 \times 10^{-2}$ & $6.08 \times 10^{-2}$ \\
Electricity $+20 \%$ & $1.60 \times 10^{-2}$ & $2.23 \times 10^{-2}$ & $3.93 \times 10^{-2}$ & $6.25 \times 10^{-2}$ \\
\hline
\end{tabular}

Figure 4. Sensitivity analysis of electricity consumption for four sludge-handling scenarios.

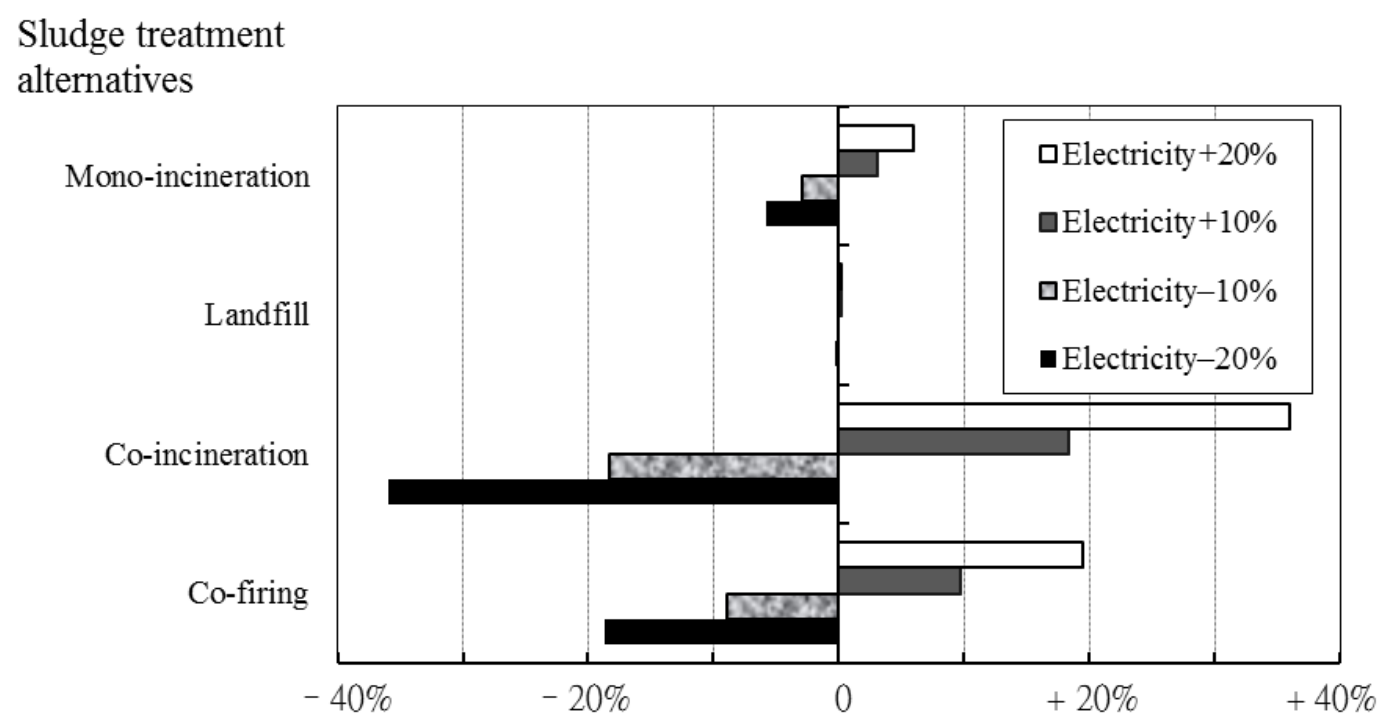

Overall impact variation based on single score (\%)

\section{Conclusions}

This study presents an assessment of the environmental effects of four sewage sludge treatment options: carbonization, mono-incineration, direct landfills, and co-incineration with municipal solid waste. This study uses an energy model to simulate the process of sewage sludge carbonization and produces theoretical energy and mass balance data for conducting the LCA. The results of the four treatment scenarios show that carbonization was the most preferable sludge-handling option overall, followed by co-incineration, landfills, and mono-incineration in descending order.

However, the co-incineration option emitted less greenhouse gases than carbonization because the overall energy recovery ratio of electricity was higher during the incineration process than during carbonization. Although this analysis considers heat recovery during carbonization, electricity generation, and coal substitution during co-firing, the energy used in drying the dewatered sludge emitted more greenhouse gases, contributing greatly to the damage category of climate change. However, changing both the feeding water content after the drying process and the carbonization temperature may mitigate the energy use of the carbonization scenario. 
The aspect of cost must also be considered in the assessment and selection of sewage sludge treatment options. Because the application of sewage sludge carbonization is currently receiving great attention from municipal authorities, the significance of sewage sludge as a valuable energy source may increase even more.

\section{Acknowledgments}

We would like to acknowledge the National Science Council of Taiwan for providing a financial support on this research.

\section{Appendix}

Table A1. Nomenclature and parameter values.

\begin{tabular}{|c|c|c|}
\hline & Nomenclature & Value \\
\hline$C_{p, b}$ & specific heat of sewage sludge (MJ/kg K) & 0.001763 \\
\hline$C_{p, w}$ & specific heat of water $(\mathrm{MJ} / \mathrm{kg} \mathrm{K})$ & 0.004187 \\
\hline$D B$ & weight of dried sludge $(\mathrm{kg})$ & 0.2 \\
\hline$D B_{\text {wet }}$ & percentage of dry solid in sewage sludge (wt \%) & 20 \\
\hline$E_{A, C G}$ & available energy from volatile gas $(\mathrm{MJ} / \mathrm{kg})$ & - \\
\hline$E_{A, C L}$ & available energy from carbonized liquid $(\mathrm{MJ} / \mathrm{kg})$ & - \\
\hline$E_{R, C}$ & energy use of carbonization unit $(\mathrm{MJ} / \mathrm{kg})$ & - \\
\hline$E_{R, D}$ & energy use of drying unit $(\mathrm{MJ} / \mathrm{kg})$ & - \\
\hline$e_{f, C}$ & efficiency of the carbonization unit & 0.85 \\
\hline$e_{f, C}$ & efficiency of the combustor unit & 0.85 \\
\hline$e_{f, D}$ & efficiency of the drying unit & 0.85 \\
\hline$L_{v, w}$ & latent heat of water at its boiling point $(\mathrm{MJ} / \mathrm{kg})$ & 2.27 \\
\hline$L H V_{\text {liquid }}$ & heating value of the carbonized liquid(MJ/kg) & $21.7^{*}$ \\
\hline$L H V_{\text {volatile }}$ & heating value of the volatile gas $(\mathrm{MJ} / \mathrm{kg})$ & $7.7^{*}$ \\
\hline$M_{\text {wet }}$ & moisture content of sewage sludge(wt \%) & 80 \\
\hline$m_{\text {in }}$ & mass of the biomass input $(\mathrm{kg})$ & 1 \\
\hline$m_{\text {out }}$ & mass of product output $(\mathrm{kg})$ & 0.08 \\
\hline$H_{L}$ & heat loss of the heat exchanger & 0.005 \\
\hline$T_{i}$ & initial temperature of sewage sludge $(\mathrm{K})$ & 298 \\
\hline$T_{C}$ & carbonization temperature $(\mathrm{K})$ & 450 \\
\hline$y_{M}$ & product yield (\%) & - \\
\hline$y_{M G}$ & volatile gas yield $(\%)$ & $26.77 * *$ \\
\hline$y_{M L}$ & carbonized liquid yield (\%) & $34.09 * *$ \\
\hline
\end{tabular}

Notes: *: Reference [24] and recalculated by this study. **: Reference [23] and recalculated by this study.

Table A2. Energy and material inputs for mono-incineration scenario.

\begin{tabular}{ccccccccc}
\hline Item & Active coal & Electricity & Heavy fuel oil & Lime & Natural gas & Polymer & $\mathbf{N a O H}$ & $\mathbf{N H}_{\mathbf{3}}$ \\
\hline Unit & $\mathrm{kg} / \mathrm{tDM}$ & $\mathrm{kWh} / \mathrm{tDM}$ & $\mathrm{kg} / \mathrm{tDM}$ & $\mathrm{kg} / \mathrm{tDM}$ & $\mathrm{m}^{3} / \mathrm{tDM}$ & $\mathrm{kg} / \mathrm{tDM}$ & $\mathrm{kg} / \mathrm{tDM}$ & $\mathrm{kg} / \mathrm{tDM}$ \\
Amount & 0.4 & 80.08 & 2.78 & 6 & 13 & 1.42 & 2.44 & 0.744 \\
\hline
\end{tabular}




\section{References}

1. Construction and Planning Agency of Taiwan Home Page. Available online: http://www.cpami.gov.tw/chinese/index.php?option=com_content\&view=article\&id=13545\&Ite mid=13123 (accessed on 7 January 2012).

2. Assessment and Planning of Sewage Sludge Disposal; Construction and Planning Agency: Taipei, Taiwan, 2011.

3. Statistics and Analysis of $\mathrm{CO}_{2}$ Emissions from Fuels Combustion; Bureau of Energy: Taipei, Taiwan, 2011.

4. Park, S.W.; Jang, C.H. Characteristics of carbonized sludge for co-combustion in pulverized coal power plants. Waste Manag. 2011, 31, 523-529.

5. Kim, Y.J.; Choi, J.H.; Kim, J.H.; Lee, C.S.; Qureshi, T.I. Production and effective utilization of carbonized sludge of industrial wastewater treatment plant. J. Chem. Soc. Pak. 2010, 32, 7-12.

6. Oda, T. Making Fuel Charcoal from Sewage Sludge for Thermal Power Generation Plant_First in Japan. In Proceedings of Water Environment Federation Technical Exhibition \& Conference, San Diego, California, USA, 13-17 October 2007.

7. Park, S.W.; Jang, C.H. Effects of carbonization and solvent-extraction on change in fuel characteristics of sewage sludge. Bioresour. Technol. 2011, 102, 8205-8210.

8. Koga, Y.; Endo, Y.; Oonuki, H.; Kakurata, K.; Amari, T.; Ose, K. Biomass solid production from sewage sludge with pyrolysis and co-firing in coal power plant fuel. Mitsubishi Heavy Ind. Tech. Rev. 2007, 44, 44-48.

9. Kimuro, Y.; Furubayashi, T.; Nakata, T. An inventory analysis of sewage energy system [in Japanese]. J. Jpn. Inst. Energy 2011, 90, 247-257.

10. Koga, Y.; Mizutani, H.; Tsuneizumi, S.; Yamamoto, H.; Tabata, M.; Amari, T. New biomass utilization technologies such as methane fermentation and pyrolysis. Mitsubishi Heavy Ind. Tech. Rev. 2007, 44, 39-43.

11. Bolin, K.M.; Dooley, B.; Kearney, R.J. Carbonization Technology Converts Biosolids to an Economical, Renewable Fuel. In Proceedings of Moving Forward Wastewater Biosolids Sustainability: Technical, Managerial, and Public Synergy, New Brunswick, Canada, 24-27 January 2007; pp. 591-597.

12. ISO 14040:2006 Environmental Management-Life Cycle Assessment-Principles and Framework; International Organization for Standardization (ISO): Geneva, Switzerland, 2006.

13. Hospido, A.; Moreira, M.T.; Martin, M.; Rigola, M.; Feijoo, G. Environmental evaluation of different treatment processes for sludge from urban wastewater treatments: Anaerobic digestion versus thermal processes. Int. J. Life Cycle Assess. 2005, 10, 336-345.

14. Hong, J.L.; Hong, J.M.; Otaki, M.; Jolliet, O. Environmental and economic life cycle assessment for sewage sludge treatment processes in Japan. Waste Manag. 2009, 29, 696-703.

15. Murray, A.; Horvath, A.; Nelson, K.L. Hybrid life-cycle environmental and cost inventory of sewage sludge treatment and end-use scenarios: A case study from China. Environ. Sci. Technol. 2008, 42, 3163-3169. 
16. Maski, D.; Darr, M.; Anex, R. Torrefaction of Cellulosic Biomass Upgrading-Energy and Cost Model. In Proceedings of American Society of Agricultural and Biological Engineers Annual International Meeting, Pittsburgh, PA, USA, 20-23 June 2010; pp. 4443-4460.

17. Syu, F.S.; Chiueh, P.T. Process simulation of rice straw torrefaction. Sustain. Environ. Res. 2012, 22, 177-183.

18. Arlabosse, P.; Chavez, S.; Prevot, C. Drying of municipal sewage sludge: From a laboratory scale batch indirect dryer to the paddle dryer. Braz. J. Chem. Eng. 2005, 22, 227-232.

19. Chiueh, P.T.; Lee, K.C.; Syu, F.S.; Lo, S.L. Implications of biomass pretreatment to cost and carbon emissions: Case study of rice straw and Pennisetum in Taiwan. Bioresour. Technol. 2012, 108, 285-294.

20. Chun, Y.N.; Kim, S.C.; Yoshikawa, K. Pyrolysis gasification of dried sewage sludge in a combined screw and rotary kiln gasifier. Appl. Energy 2011, 88, 1105-1112.

21. Lou, R.; Wu, S.; Lv, G.; Yang, Q. Energy and resource utilization of deinking sludge pyrolysis. Appl. Energy 2012, 90, 46-50.

22. Bergman, P.C.A.; Boersma, A.R.; Zwart, R.W.R.; Kiel, J.H.A. Torrefaction for Biomass Co-Firing in Existing Coal-Fired Power Stations; ECNC050132005; Energy Research Centre of the Netherlands (ECN), ECN Biomass: Petten, The Netherlands, 2005.

23. Fonts I.; Juan A.; Gea, G.; Murillo, M.B.; Sanchez, J.L. Sewage sludge pyrolysis in fluidized bed, 1: Influence of operational conditions on the product distribution. Ind. Eng. Chem. Res. 2008, 47, 5376-5385.

24. Fonts, I.; Kuoppala, E.; Oasmaa, A. Physicochemical properties of product liquid from pyrolysis of sewage sludge. Energy Fuel 2009, 23, 4121-4128.

25. Jolliet, O.; Margni, M.; Charles, R.; Humbert, S.; Payet, J.; Rebitzer, G.; Rosenbaum, R. IMPACT 2002+: A new life cycle impact assessment methodology. Int. J. Life Cycle Assess. 2003, 8, 324-330.

26. Tyagi, V.K.; Lo, S.L. Enhancement in mesophilic aerobic digestion of waste activated sludge by chemically assisted thermal pretreatment method. Bioresour. Technol. 2012, 119, 105-113.

27. Environmental Protection Administration of Taiwan Home Page. Available online: http://ivy4.epa.gov.tw/swims/swims_net/index.aspx (accessed on 7 January 2012).

28. Houillon, G.; Jolliet, O. Life cycle assessment of processes for the treatment of wastewater urban sludge: energy and global warming analysis. J. Clean Prod. 2005, 13, 287-299.

29. Lundin, M.; Olofsson, M.; Pettersson, G.J.; Zetterlund, H. Environmental and economic assessment of sewage sludge handling options. Resour. Conserv. Recycl. 2004, 41, 255-278.

30. Svanstrom, M.; Froling, M.; Olofsson, M.; Lundin, M. Environmental assessment of supercritical water oxidation and other sewage sludge handling options. Waste Manag. Res. 2005, 23, 356-366.

(C) 2013 by the authors; licensee MDPI, Basel, Switzerland. This article is an open access article distributed under the terms and conditions of the Creative Commons Attribution license (http://creativecommons.org/licenses/by/3.0/). 